Research Article / Научная статья

\title{
Religious Pluralism Concept of M. Mendelssohn and Its Theoretical Foundation
}

\author{
L.E. Kryshtop \\ RUDN University \\ Miklukho-Maklaya str. 6, Moscow, Russian Federation, 117198
}

\begin{abstract}
The article consider the concept of religious pluralism by M. Mendelssohn and some aspects of his theory of knowledge and linguistic theory, lying in the foundation of the pluralism concept. The article shows that Mendelssohn expressed views that are far ahead of his time. His theory of knowledge repeats some lines of Hume's philosophy, which he praised highly, what was not characteristic of the German Enlightenment as a whole. By virtue of this, Mendelssohn can be considered as Kant's predecessor in a positive assessment of Hume. Some of Mendelssohn's ideas are further developed in phenomenology. The author argues that Mendelssohn's views on the interaction of religions, although they have a number of features that make this thinker related to other thinkers of the Enlightenment, also have a fundamental difference with them. As a result, his religious pluralism concept is close to the modern understanding of religious pluralism. The author also attempts to reveal the reasons why Mendelssohn, despite his great significance for both German philosophy and Jewish culture, was almost forgotten for a long time.
\end{abstract}

Keywords: Mendelssohn, religion, pluralism, theory of knowledge, truth, reality, language

Funding and Acknowledgement of Sources. The reported study was funded by RFBR, project number 18-011-00080.

\section{Article history:}

The article was submitted on 24.01.2020

The article was accepted on 20.04.2020

For citation: Kryshtop L.E. Religious pluralism concept of M. Mendelssohn and its theoretical foundation. RUDN Journal of Philosophy. 2020; 24 (3): 328 - 341. DOI: 10.22363/2313-23022020-24-3-328-341

\section{Introduction}

Moses Mendelssohn is a well-known contemporary of Kant. He enjoyed unprecedented popularity comparable to Lessing's fame [1. S. 16] and in some ways

(C) Kryshtop L.E., 2020

This work is licensed under a Creative Commons Attribution 4.0 International License https://creativecommons.org/licenses/by/4.0/ 
was even more significant for his time than Kant [2. S. 85-90]. However, nowadays Mendelssohn is not mentioned so often and for the most part it occurs in the context of discussions about the Jewish Enlightenment. In fact we can find in his writings a number of topics indicated that Mendelssohn was much ahead of his epoch. Some of his views are much closer to the current state of affairs than the views of most Enlightenment thinkers. Some of them do not lose their relevance also today and may be useful for us. First of all, this is the theory of religious pluralism, closely related to the theory of cognition of Mendelssohn.

\section{Mendelssohn's theory of religious pluralism}

Views on religion as such and the problem of the relationship between different religions among themselves become the subject of Mendelssohn's later writing Jerusalem or Religious Power and Judaism (1783). The history of raise of this treatise is of interest. For a long time it was supposed that Mendelssohn was strongly influenced by the views of Spinoza expressed in his Theological-political Treatise $(1670)^{1}$. This point of view can be met also today. But the more actual now is other opinion, namely that defend Mendelssohn's independence in the process of creating this work ${ }^{2}$. But however in fact the work is essentially apologetic and caused by the growing process of the struggle of Jews for emancipation, which is ongoing both at the legislative and intellectual levels [6. S. IX-XIII]. Such point was evidently consistent with the main features of German Enlightenment philosophy and its self-understanding. It was reflected at the large extend in the struggle against all possible sorts of prejudices and superstitions, that in case of Mendelssohn took the form of the struggle against a very number of prejudices related to the Jews ${ }^{3}$.

In view of this apologetic orientation of the treatise, it is not surprising that a significant number of the points expressed by Mendelssohn are aimed directly at defending and interpreting Judaism, that allows many researchers to concentrate on

1 This thesis is based on the similarity of the conclusions reached by both thinkers [3. S. 31-67; 25. P. 107-116; 4. P. 44].

${ }^{2} \mathrm{~F}$. Niewöhner adheres to this point of view, proving that Mendelssohn was not familiar with the Theological-political Treatise itself, but only heard about it [5. S. 298], though that it is incorrect to talk about the direct dependence of Mendelssohn's views on Spinoza and we should consider Jerusalem as based on the social situation of Jews in the second half of the $18^{\text {th }}$ century [5. S. 303]. In my opinion this point of view is correct.

3 Mendelssohn is often called the "Jewish philosopher". It has already occurred by his contemporaries [9. S. 54]. But at that time this meant only his nationality. Subsequently, a different meaning was put into this characteristic and it has been began to perceive in Mendelssohn the representative of Jewish philosophy [8. S. 246; 29. S. 137-138]. The failure of this approach was demonstrated by F. Niewöhner, who noted that Mendelssohn was never limited himself to the desire to be only a representative of Jewish philosophy [5. S. 292]. Despite Mendelssohn's clear articulation of his own position regarding the Jewish people and Judaism, it would be incorrect to assert that expressing opinions on this subject was his only goal and was planned by him in advance. We have more reasons to state that Mendelssohn would never have come to a decision to formulate his view on these issues without challenges from Christian philosophers contemporaries of him [3. S. 303]. 
the contradictions in the interpretation of Judaism presented in Jerusalem which seems there to be a religion nearly identical with the religion of reason $[3 ; 9$. S. 234-248; 10. P. 29-45; 36]. Such an opinion, with its further development, leads us in fact to a number of contradictions insoluble on the basis of Mendelssohn's treatise itself. A. Altmann expressed the main of them. In his opinion, Mendelssohn insisted, that Judaism is rooted in truths of reason. They are universal and absolutely necessary for salvation. But at the same time Mendelssohn believed as all Jews around that these universal truths had been revealed by God to the chosen people (t. i. Jews). Altmann assumed that these two statement of Mendelssohn are contradictory and demonstrated the conflict between truth and revelation characteristic for Mendelssohn, which could be explained by reference to his Jewish origins building a particular combination with Enlightenment attitude [9. S. 247]. Earlier researchers noted this Mendelssohn's inconsistency too. Thus, J. Guttmann has already noticed the strict distinction between the religion of reason and the Jewish Law occurring in the philosophical writings of Mendelssohn [3. S. 32].

These contradictions by Mendelssohn is easy to notice. But one could also find out that Mendelssohn himself considered in his writing not only the universal component of Judaism, but also paid attention to the historical side of his peoples' religion and interpreted it only as the third and the least impotent component, thus, albeit implicitly, giving in Judaism priority to the truths of reason. And that last shows most clearly his unorthodoxy [11. S. 218]. As a result a constant tension between the Mendelssohn-Jew and the Mendelssohn-philosopher is mentioned in the Jerusalem [9. P. 247-248; 12. S. 145-146]. And it is this state of affairs that often causes the fact that one doesn't notice in Mendelssohn's writing a point very significant for him, namely an appeal to religious pluralism. And it is worth surprising that Mendelssohn understands it in the same way as is characteristic for contemporary supporters of this idea, the most famous of which is J. Hick [13. S. 480-488].

Briefly consider the main thesis of Mendelssohn's theory of religious pluralism. Like many Enlightenment thinkers, Mendelssohn set aside fundamental religious truths. He counted to them the existence of God, the faith in his providence and in the immortality of the soul in the afterlife, without which love for people is nothing but innate weakness [14. S. 65]. These truths could be known through the human reason and though they are the core of the natural religion. But the same truths we find out in the revealed religion. Thus, this foundation can be considered as universal and common for all religions, if we only digress from the specific forms of expression of faith in them, dictated by the culture and history of different peoples. In this way Mendelssohn came to the conclusion that both religious ceremonies as well as dogmatic are just the inherent elements building up on the base of this fundamental religious truths.

Mendelssohn builds his concept of tolerance and religious pluralism on this foundation. All religions are good and acceptable if their private doctrines (the dogmatic and cult superstructures) do not contradict the fundamental religious 
truths and peaceful coexistence of citizens in the state (what we might call today "do not incite religious discord"). Thus, Mendelssohn also involves the state in this process, which is called on to ensure that not one of the religions enters into enmity with other religions and does not oppress the faithful of other religions, thereby violating the peace and safety of the society [14. S. 64-65].

We see that such position regarding religions is not so far from our current approach, especially if we replace the three truths proposed by Mendelssohn with "the values of humanity" or "human rights". But in this aspect, however, Mendelssohn was not particularly original in comparison with other thinkers of the Enlightenment. A similar concept was offered, in particular, by I. Kant [15. P. 156-165]. But we are able to find also a fundamental difference. For many philosophers of the Enlightenment, it was more common to consider the diversity of historical religions merely as an intermediate stage in the development of mankind. And the true religion was considered to be either deism (for example, by H.S. Reimarus) or some varieties of the natural religion (such as the moral religion of reason by I. Kant), or some genuine moral teaching of Christ (like most moderate neologians), or perhaps yet still unknown religion (as by G.E. Lessing). Thus, relating to the questions what must be the true religion we find a broud verity, but it was the statement that this true religion can be universal and only one and the same for all peoples all over the world that the most of the thinkers of the Enlightenment had in common. It is to her as a result of gradual improvement that all of humanity should come. Historical religions should eventually recede into the past. Thus, they can be acceptable, but only for a while, and only to the extent that they contribute to the approach to the true religion and its gradual spread. Accordingly, the closer a historical religion to the true religion, the more suitable it is. And in most cases, it was Christianity that turned out to be the most suitable of all.

Mendelssohn considers the issue in a different way. For him, all religions that do not contradict the three fundamental truths are equivalent in their value. They all have right to continue their existence, in peaceful coexistence with each other. Hereby, Mendelssohn did not just not call for the elimination of religious diversity and its reduction in the future (albeit distant) to an universal religion, he believed that this diversity was inevitable and did not at all contradict God's plan for a mankind. And in the pursuit of universalizing characteristic in such large extent for the Enlightenment, Mendelssohn saw the threat of subjugation of personality, individuality in all its diversity, to the cold dictate of falsely understood rationality.

But exactly in this point the question arises of how Mendelssohn tried to reconcile such a pluralistic view with the faith of Judaism, since the fact that Mendelssohn remained a practicing Jew throughout his life is beyond doubt. From this point of view the positions of those scholars who believe that Mendelssohn's entire philosophy is permeated by a permanent dispute between its philosophical and Jewish components become quite understandable. In order to clarify this issue, we should turn to a short review of Mendelssohn's theory of knowledge no less worth then his concept of religious pluralism. 


\section{Theory of knowledge of M. Mendelssohn}

The theory of knowledge of Mendelssohn is formulated the most detailed and systematized in Morning Hours, or Lectures on the Existence of God (1785) [16. S. 215-334]. J. Schoeps sees precisely in this work the core of Mendelssohn's theoretical philosophy, believing it to be the most systematic of all the works of this thinker [12. S. 153]. This writing contains many significant thoughts relevant also for today. However, in order to develop our theme, it is necessary at the first line to dwell on Mendelssohn's views on truth and reality.

Mendelssohn defines truth as the correspondence between words, concepts and things [16. S. 223]. Herewith, just as the truth of words can be established by comparing them with thoughts (concepts), the truth of thoughts should be established by comparing them with the objects themselves. And now Mendelssohn formulates a profound remark, which is also for today one of the main weaknesses of the correspondence theory of truth. And namely, in order to establish the truth of concepts by comparing them with the objects themselves, these objects themselves must be given to us regardless of our concepts about them, what is just impossible, since we have access to objects only indirectly, through our perception, i.e. instead of the objects themselves, we always deal only with their reflection in our consciousness [16. S. 223]. This provides Mendelssohn to the need to separate two spheres - the sphere of thinking and the sphere of reality [16. S. 267].

Both of these spheres obey different laws. The sphere of thinking is based on the law of contradiction [16. S. 227, 243] and represents the totality of all thinkable. Here it is possible to achieve the highest degree of certainty - mathematical certainty or pure certainty of reason (reine Vernunftevidenz) [16. S. 268]. But in order to conclude from the possibility of an object to its reality, the law of contradiction is no longer enough [16. S. 225]. But since the just thinkable in some sense also exists, Mendelssohn suggests distinguishing between different types of existence, depending on the types of the objects. Everything thinkable is characteristic with the mode of ideal reality or reality of representations (Würklichkeit der Vorstellungen). But besides this kind of reality, there is another type of reality - actual reality or the reality of represented things (Würklichkeit des vorstellenden Dinges). Herewith the conclusion from the first kind of reality to the second is problematic [16. S. 226].

Mendelssohn identifies three different kinds of things: thoughts, the thinking subject, and the thinkable [16. S. 226]. The first type of thing includes everything thinkable, i.e. everything possible. These things obey the law of contradiction and they are inherent in ideal reality. There are also no difficulties with establishing of reality of the second kind of things - the thinking subject. Human being himself is the source of all his knowledge. He always comes out of himself in cognition. All my ideas, the ideal reality of which is obvious, are some changes in my thinking. I perceive them in me and that is the reason, why I predicate to them ideal reality. But this means that the Self is not in itself just a thought, but it is a truly existing thing. Thus, the reality of ourselves is also absolutely certain and turns out to be the 
starting point of our knowledge [16. S. 225-226, 245-246]. And all my subjective knowledge, i.e. my ideas, while they are considered as subjective (as mere representations) is inherent in ideal reality and cannot be mere delusion. Just as my own existence cannot be a delusion [16. S. 246]. In this case, Mendelssohn explicitly refers to the Cartesian "cogito, ergo sum", while understanding "I think" extremely broadly, as the entire internal sphere of a person, including not only thoughts and ideas, but also sensory perceptions and emotions [16. S. 245-246].

Difficulties arise with the establishment of reality of the third kind of things external objects, those prototypes of our ideas. Reality must be inherent in them (otherwise they would be only our ideas). When we try to turn on to this kind of things, we stop considering our ideas as subjective and try considering them as objective [16. S. 243]. And it is here, according to Mendelssohn, that the core of mistakes and errors is hidden: our feelings and thoughts themselves do not contain errors as such, an error can appear only when the transition from them to the external objects is wrong [16. S. 242-243].

How does this transition happen? And what are the grounds for predicating to something the actual reality (real existing)? In this case, a person relies on the data of feelings. He is inclined to consider as really existing what affects his feelings (external or internal). Hereby, the greater the consistency in the data on the object from different senses, the greater the confidence in the real existence of the object acting on them [16. S. 226-227]. Even more convincing is the correspondence in the perception of different people, although Mendelssohn makes a reservation that different people can never perceive the same object in exactly the same way, since their perception is always depend on a number of different internal and external conditions, and therefore, agreement here will always be relative [16. S. 253, 227]. In any case, we will never achieve the mathematical certainty upon the existence of this kind of things. The only degree of certainty available to us in this case is the certainty of faith based on probability and inductive method [16. S. 227].

In order to illustrate this fundamental position, Mendelssohn gives an example with a room in which instead of walls there will be only mirrors. An object placed in the center of such a room will have a great many reflections, so it will be difficult to establish exactly where the object is and what it really is. The question will also be whether it exists at all. However, comparing different images, we can conclude that something in them remains unchanged. And it is this unchanging in all reflections that will be the properties of the object itself, while changes will depend on different perspectives. The situation is the same with the human cognition. In the consciousness of each person not the objects themselves are given, but their reflections. And they can differ from different human beings. But if we can find in them something unchanging, repeating by different human beings and under different circumstances, then we will be inclined to call it a real object, and 
predicate everything else to certain subjective characteristics of perception [16. S. 275].

Thus, we see that Mendelssohn was skeptical about the possibility of knowing a certain reality outside of our consciousness. He considered the transition from our ideas to things outside of us problematic in itself. In this case, Mendelssohn clearly follows the Hume theory of knowledge, which, in general, was not common for German Enlightenment. Hume was considered rather as a threat to morality and religion and his philosophy was subjected to devastating criticism. In this case, Mendelssohn can be seen as Kant's predecessor in perception of Hume philosophy not as a threat, but as a challenge and a task requiring deep understanding and solution [17. S. 139-140]. However, with an equally evidence, we can see in Mendelssohn's theory of cognition some lines of thought that will be expressed already in $20^{\text {th }}$ century by phenomenologists [18. S. 345].

But in order to understand the concept of religious pluralism of Mendelssohn better, we need to analyze one more aspect of his theory of knowledge, no less progressive for his time - his views on language and his role in human knowledge of truth. Of the language Mendelssohn was also very skeptical. He considered language only as a means of communication, a means of transferring his ideas to another person, which works fine if the ideas remain inherent in their ideal reality. And what of language as an instrument of achieving of certain knowledge, Mendelssohn was extremely skeptical. Reality outside our consciousness is accessible to us only in a problematic way, and the use of language, albeit conventionally established, does not change the essence of the matter of fact. In other words, expressing our ideas in linguistic form does not in itself transform the mode of ideal reality inherent in it into the mode of actual reality.

Such a view of Mendelssohn on truth and its comprehension and the role of language in human life are of fundamental importance for understanding the concept of religious pluralism of Mendelssohn, while becoming, in fact, its foundation. What truth is in itself (if we mean herewith an actual reality outside the human consciousness) is inaccessible to us. We can draw some conclusions regarding this, based on the testimonies of different senses of ourselves and the agreement in the testimonies of objects of different persons. However, this will always be problematic and can never claim to be mathematical certainty. In transmitting testimonies to other persons and in perceiving their testimonies, a person relies on language, which in turn can transmit these testimonies in a more perfect or less perfect form. Thus, language does not just perform an important function, but it is simply necessary, since without it it would not be possible to learn something about the experience of other human beings, and therefore, it would not be possible to compare one's perception with perception of other persons and come to more certain conclusions ${ }^{4}$.

\footnotetext{
${ }^{4}$ More about Mendelssohn's views on language in the context of linguistic theories of the Enlightenment see: [19. S. 195-241; 20. S. 99-122; 21. S. 40-42].
} 
This is the case with all kinds of truths, including the truths of Divine Revelation. Mendelssohn did not question the reality of Divine Revelation. However, he reduced its essence to a certain relationship of the person with God, to a covenant, a certain obligation of the person towards God, which does not cease to exist under any circumstances. But this innate connection is internal. And when human beings would like or just would hold for necessary to make it explicit, it could be expressed only through words. And this particular verbal expression can differ from generation to generation and from people to people. And precisely to these specific verbal expressions Mendelssohn counts, among other things, all the truths of faith, which, for this reason, are also subject to transformation over time [22. S. 147-155; 23. P. 13]. And on the same foundation, he build his concept of religious pluralism, implying a variety of private, individual religious practices based on a living, innate, but differently interpreted and verbalized connection with God [22. S. 145; 24. S. 89-92; 25. S. 142, 151-152; 26. S. 33].

\section{Reception of Mendelssohn's thought}

As we saw on the basis of the previous analysis, Mendelssohn has formulated a number of ideas that have not lost their relevance today. In this regard, I would also like to pay some attention to what made possible the immersion of his philosophical views in such a long oblivion. This question itself is of considerable historical and philosophical interest, since the attitude of different epochs and different thinkers to Mendelssohn says a lot about these epochs and thinkers themselves.

The attitude towards Mendelssohn has been ambiguous and remains ambiguous today. The value of his views, his activities (in particular, the translation of the Bible into German) and his very image (contrary to the image of a Jew of that time) are not disputed by anyone. However, estimates of this value vary widely. Moreover, it is precisely in assessment of Mendelssohn that we can most clearly notice the influence on the formation of his image in the subsequent tradition of the most diverse factors external to the philosophy of Mendelssohn himself. This influence can be traced both in the assessment by European thinkers (mostly of the Christian tradition), and in relation to him in the framework of the Jewish tradition itself.

Let us first consider the attitude towards Mendelssohn in the midst of Judaism. It depended heavily on the specific historical, social and political circumstances of the existence of different Jewish communities in different European countries [27. S. 24]. Speaking about the perception of Mendelssohn among his own Jewish community in Berlin, as well as the young Jewish communities of Northern Europe, it can be noted that Mendelssohn's activities, including translating the Bible, found support, but mainly only among the wealthy stratum of Jews and Jews of young age, which since the middle of the $18^{\text {th }}$ century began to adopt the lifestyle of the European elite [28. P. 336-342]. In an orthodox milieu, on the contrary, Mendelssohn was treated critically or, at least, with great caution, because of 
believing his views to be a betrayal of the national tradition. Despite all the assurances of Mendelssohn that he strives only for synthesis, for a balance between the national tradition of Judaism and objective external requirements, and strict observance by Mendelssohn himself of the main ritual prescriptions of Judaism [8. S. 245-246; 23. P. 16; 28. S. 342; 29. S. 172; 40. S. 236], it was considered, especially after the translation of the Pentateuch, that it was not so much an expresser of traditional culture seeking to fulfill mediation functions, but a representative of a new reform movement, which in fact was not far from the truth. Perhaps not wanting it himself ${ }^{5}$, Mendelssohn's activity marked the first stage on the path to reforming Judaism [8. S. 245; 23. P. 15-17; 26. S. 67; 31. S. 98]. It ist true, that Mendelssohn saw the ritual norms as distinguishing Jews from other nations and considered them to be necessary to follow. But we can also state that he laid the foundations of a subsequent movement to soften the rabbinical control of Jewish daily life while breeding the concept of truths of faith and ritual laws transmitted to the Jews through the Revelation, as well as emphasizing the voluntary character of following the latter [31. S. 92, 98; 32. S. 353-354]. It is for this reason that the next generation of reformers took Mendelssohn as their predecessor [32. S. 354-355]. In the further time the reformist movement in the North of Germany only intensified. That led to a fairly quick reappraisal of Mendelssohn's views: if during his life he was considered a radical critic of tradition, then among the Jews of the next generation he was considered a thinker with moderate (and even too moderate) views [32. S. 356].

The attitude to Mendelssohn in Eastern Europe (including Hungary) was completely different. The orthodox rabbinical wing had a much greater influence here $^{6}$, so the reformation took much milder forms here: there was no rational criticism of the ritual laws (which took place among the radical reformers of the next generation after Mendelssohn), there were no attempts to radically overthrow the yoke of rabbinic control. As it might seem, such a reform approach was closer to that proposed by Mendelssohn. However, Mendelssohn was not destined to become the idol of these territories, since the significant influence that the mystical movement acquired in these territories led to sharp criticism of the rationalistic tradition, the symbol of which Mendelssohn had become [32. S. 356-358].

As a result, it can be stated that the attitude towards Mendelssohn among the Jews themselves was critical, though for various reasons. In Western Europe, Mendelssohn was initially cautious in view of his reformist aspirations, but very quickly he became insufficiently radical and too moderate. For Eastern Europe he was too radical and rationalistic from the very beginning. However, in all Europe around (both Eastern as well as Western) there was a tendency to ascribe the

\footnotetext{
${ }^{5}$ Mendelssohn is sometimes described as a "silent reformer". This characteristic dates back to the work of J. Unger [30].

${ }^{6}$ The same is true for the old communities of Western Europe, for example, the communities of Hamburg, Frankfurt am Main, as well as the communities of Prague, Vilnius, etc., where attitude towards Mendelssohn was extremely critical from the very beginning [28. P. 342].
} 
beginning of the processes of Jewish Enlightenment and reforming to the strength of one single person, namely M. Mendelssohn [32. S. 357].

An essential change to Mendelssohn among the Jews occurs in the 70s of the $19^{\text {th }}$ century. The reason was the activity of Peretz Smolenskin, a representative of the Russian Haskala and one of the forerunners of Zionism. According to him, Mendelssohn provoked the process of denationalization of the Jews, their assimilation with European culture and the betrayal of the Jewish tradition. To confirm his point of view, Smolenskin referred to the well-documented fact of the so-called epidemic of baptism (significant increase of a number of Jews let them to be baptized), which followed the wave of the second generation of reformers [32. S. 361]. Four children of Mendelssohn himself have also been baptized [28. P. 343]. At first, Smolenskin's point of view was not decisive. Mendelssohn had many defenders who refuted the opinion of Smolenskin. However, the ensuing series of pogroms soon contributed to formalizing his ideas in the political movement, and his assessment of Mendelssohn for a long time became dominant among the Jewish people [32. S. 362].

Speaking about the attitude towards Mendelssohn among the philosophers of the West European philosophical tradition, it should be noted that a re-evaluation of his work by German idealists can be considered a turning point that has long determined the image of this thinker. Mendelssohn was perceived as hostile. He was criticized for the superficiality and simple popularization of the WolfianLeibnizian tradition. But it is important to note that in this case the German idealists were not so much interested in Mendelssohn himself, as in the whole Enlightenment as such, of which Mendelssohn became the symbol. Criticizing Mendelssohn, these thinkers criticized the entire German Enlightenment as such.

Another important aspect of the formation of the Mendelssohn's image within the framework of German idealism is that, despite the interest and familiarity of the German idealists with the texts of Mendelssohn himself, their assessment turned out to be derived from the views of Jacobi, who criticized the Enlightenment for its excessive rationalization and lack of a living faith, as well as understanding the limitations of the human mind, unable to penetrate the deep secrets of the universe. Altmann drew attention to this and has put forward the thesis that the degree of criticality towards Mendelssohn is directly dependent on proximity to Jacobi. Thus, Hegel was the most critical of $\mathrm{Jacobi}^{7}$ and by him we find the most positive assessment of Mendelssohn. The most critical of Mendelssohn was Fichte, who best treated Jacobi [33. S. 16-19]. For this reason, the central moment in creating the image of Mendelssohn as a banal thinker mired in Wolffianism, according to Altmann, is the analysis of Jacobi's attitude to Mendelssohn. In fact, it was Jacobi, who created this image, which was far from the truth, but has become tenacious and influential through German idealists. Moreover, Altmann believes that this was done by Jacobi completely consciously, but again not with the purpose of

\footnotetext{
${ }^{7}$ It should be also noted that Hegel was well acquainted with some of the works of Mendelssohn, especially with his Jerusalem [33. S. 15-16; 23. P. 9].
} 
discrediting the name of Mendelssohn himself or the Jewish people in him, but in order to discredit the Enlightenment, the most outstanding and typical representative of which Mendelssohn was considered at that time [3. S. 6-7].

The inadequacy of this critical image of Mendelssohn, which led to the unjust forgetfulness of this thinker, began to be noticed already in the middle of the $19^{\text {th }}$ century [34. S. 87]. From that moment, interest in Mendelssohn as an outstanding representative of the German Enlightenment began to increase gradually [35. S. 480 - 488; 41. S. 333 - 348]. However, for a long time, the image created by Jacobi remained dominant. We can say that significant changes were achieved only in the second half of the $20^{\text {th }}$ century, when the first attempts were made to an uninterested, impartial, open-minded analysis of the work of this thinker [36. S. 5]. The leading contribution to this process was made by A. Altmann, the founder of modern Mendelssohn studies, "who took the meaning of the life and work of Moses Mendelssohn from the shadow of the past into the light of a new understanding" [37. S. IX].

\section{Conclusion}

Summing up we can conclude that Mendelssohn's theory was truly progressive for its time. That was confirmed in the subsequent development of philosophy in Europe in the $20^{\text {th }}$ century. Mendelssohn's views on language and its role in human cognitive activity remain no less relevant. What for the religious pluralism theory of Mendelssohn it strikes in its confirming with the current state of affairs in religion studies, especially related to the research of so called religious experience and its epistemological value. Oblivion, which befell Mendelssohn for more than a century, was in no way connected with the lack of depth of thought in the works of this thinker. The ground for it was rather external factors of development of both European and Jewish cultures.

\section{References}

[1] Bracker J. Moses Mendelssohn, ein Gegenbild des „Ewigen Juden“. In: Ich handle mit Vernunft ... Moses Mendelssohn und die europäische Aufklärung. Hg. v. N Hinske. Hamburg: Felix Meiner Verlag; 1981. S. 15-44. (In German).

[2] Hinske N. Mendelssohns Beantwortung der Frage: Was ist Aufklärung? Oder Über die Aktualität Mendelssohns. In: Ich handle mit Vernunft ... Moses Mendelssohn und die europäische Aufklärung. Hg. v. N Hinske. Hamburg: Felix Meiner Verlag; 1981. 85-118. (In German).

[3] Guttmann J. Die Philosophie des Judentums. München: Reinhardt Verlag; 1933. (In German).

[4] Bourel D. Introduction. In: Mendelssohn M. Jérusalem ou pouvoir religieux et judaïsme. Ed. par D. Bourel. Paris: Les presses d'aujourd'hui; 1982. P. 23-50. (In French).

[5] Niewöhner Fr. „Es hat nicht jeder das Zeug zu einem Spinoza“. Mendelssohn als Philosoph des Judentums. In: Moses Mendelssohn und die Kreise seiner Wirksamkeit. Hg. v. M Albrecht, EJ Engel, N Hinske. Tübingen: Max Niemeyer Verlag; 1994. S. 291-313. (In German). 
[6] Albrecht M. Einleitung. In: Mendelssohn M. Jerusalem oder über religiöse Macht und Judentum. Hg. v. M. Albrecht. Hamburg: Felix Meiner Verlag; 2005. S. VII-LXIV. (In German).

[7] Berwin B. Moses Mendelssohn im Urteil seiner Zeitgenossen. Berlin: Reuther \& Reichard; 1919. (In German).

[8] Bourel D. Nachwort. Die Treue und die Freiheit Mendelssohns. In: Mendelssohn M. Morgenstunden oder Vorlesungen über das Dasein Gottes. Der Briefwechsel Mendelssohn - Kant. Hg. v. D Bourel. Stuttgart: Philipp Reclam Verlag, 1979. S. 243-266. (In German).

[9] Altmann A. Moses Mendelssohn's Concept of Judaism Reexamined. In: Von der mittelalterlichen zur modernen Aufklärung. Hg. v. A Altmann. Tübingen: J.C.B. Mohr Siebeck Verlag; 1987. S. 234-248.

[10] Arkush A. The Questionable Judaism of Moses Mendelssohn. In: New German Critique. 1999.Vol. 77. P. $29-45$.

[11] Berghahn C-F. Moses Mendelssohns „Jerusalem“: ein Beitrag zur Geschichte der Menschenrechte und der pluralistischen Gesellschaft in der deutschen Aufklärung. Tübingen: Niemeyer; 2001. (In German).

[12] Schoeps JH. Moses Mendelssohn. Königstein: Jüdischer Verlag; 1979. (In German).

[13] Schick F. Philosophie der Religionen statt Vernunfttheologie?. In: Religion und Religionen im Deutschen Idealismus. Hg. v. F Hermanni, B Nonnenmacher, F Schick. Tübingen: Mohr Siebeck; 2015. S. 477-499. (In German).

[14] Mendelssohn M. Jerusalem oder über religiöse Macht und Judentum. Hg. v. M Albrecht. Hamburg: Felix Meiner Verlag; 2005. (In German).

[15] Kryshtop LE. State and Church by Kant and Mendelssohn. In: Russian Studies in Philosophy; 2015. Vol. 12. P. 156-165 (In Russian).

[16] Mendelssohn M. „Morgenstunden oder Vorlesungen über das Daseyn Gottes“. In: Mendelssohn M. Ausgewählte Werke. Bd. 2. Hg. v. Ch Schulte, A Kennecke, G Jurewicz. Darmstadt: WBG; 2009. S. 215-334. (In German).

[17] Lühe A. „Catarcticon“ oder „organon“. Kausalität und Induktion bei Hume und Mendelssohn. In: Moses Mendelssohn im Spannungsfeld der Aufklärung. Hg. v. M Albrecht, EJ Engel. Stuttgart-Bad Cannstatt: Frommann-Holzboog Verlag; 2000. S. 137-158. (In German).

[18] Dahlstrom DO. Truth, Knowledge, and "the Pretensions of Idealism": A Critical Commentary on the First Part of Mendelssohn's Morning Hours. In: Kant-Studien, 2018. Vol. 109 (2). S. 329-351.

[19] Ricken U. Mendelssohn und die Sprachtheorien der Aufklärung. In: Moses Mendelssohn im Spannungsfeld der Aufklärung. Hg. v. M Albrecht, EJ Engel. Stuttgart-Bad Cannstatt: Frommann-Holzboog Verlag; 2000. S. 195-241. (In German).

[20] Westerkamp D. Zeichen der Phantasie. Mendelssohns Sprachphilosophie der Aufklärung. In: Moses Mendelssohn. Hg. v. HL Arnold, C-Fr Berghahn. München: Richard Boorberg Verlag; 2011. S. 99-122. (In German).

[21] Berghahn C-Fr. Mendelssohn übersetzt Rousseau und erklärt ihn Lessing. Strategien kulturkritischen Schreibens in der europäischen Aufklärung. In: Moses Mendelssohn. Hg. v. HL Arnold, C-Fr Berghahn. München: Richard Boorberg Verlag; 2011. S. 26 - 44. (In German).

[22] Martyn D. Nachwort. In: Mendelssohn M. Jerusalem oder über religiöse Macht und Judentum. Vorrede zu Manasseh Ben Israels ,,Rettung der Juden“. Hg. v. D Martyn. Bielefeld: Aisthesis Verlag, 2001. S. 137-155. (In German).

[23] Levinas E. Préface. In: Mendelssohn M. Jérusalem ou pouvoir religieux et judaïsme. Ed. par D Bourel. Paris: Les presses d'aujourd'hui; 1982. P. 7-21. (In French). 
[24] Goetschel W. Einstimmigkeit in Differenz. Der Begriff der Aufklärung bei Kant und Mendelssohn. In: Moses Mendelssohn. Hg. v. HL Arnold, C-Fr Berghahn. München: Richard Boorberg Verlag; 2011. S. 79-98.

[25] Martyn D. „Jerusalem“ und die jüdische Säkularisierung. Mendelssohn contra Hegel. In: Moses Mendelssohn. Hg. v. HL Arnold, C-F. Berghahn. München: Richard Boorberg Verlag; 2011. S. 140-158. (In German).

[26] Thom M. Einleitung. In: Mendelssohn M. Schriften über Religion und Aufklärung. Hg. v. M Thom. Darmstadt: WBG; 1989. S. 7-74. (In German).

[27] Bourel D. Moses Mendelssohn. Begründer des modernen Judentums. Zürich: Ammsnn Verlag; 2007. (In German).

[28] Lowenstein SM. The Social Dynamics of Jewish Responses to Moses Mendelssohn (with Special Emphasis on the Mendelssohn Bible Translation and on the Berlin Jewish Community). In: Moses Mendelssohn und die Kreise seiner Wirksamkeit. Hg. v. M Albrecht, EJ Engel, N Hinske. Tübingen: Max Niemeyer Verlag; 1994. P. $333-348$.

[29] Bourel D. Nachwort zur Entstehung des „Phädon. In: Mendelssohn M. Phädon oder über die Unsterblichkeit der Seele. Hg. v. D Bourel. Hamburg: Felix Meiner Verlag; 1979. S. 161-173. (In German).

[30] Unger JJ. Der stille Reformator. Denkrede auf Moses Mendelssohn zur Feier seines hundertsten Sterbetages am 2. Januar 1886. Iglau; 1886. (In German).

[31] Jakobs RA. A Jewish Reading of Moses Mendelssohn's Response to Lavater. In: Moses Mendelssohn im Spannungsfeld der Aufklärung. Hg. v. M Albrecht, EJ Engel. StuttgartBad Cannstatt: Frommann-Holzboog Verlag; 2000. S. 89-100. (In German).

[32] Katz J. Moses Mendelssohns schwankendes Bild bei der jüdischen Nachwelt. In: Moses Mendelssohn und die Kreise seiner Wirksamkeit. Hg. v. M Albrecht, EJ Engel, N Hinske. Tübingen: Max Niemeyer Verlag; 1994. S. 349-362. (In German).

[33] Altmann A. Das Bild Moses Mendelssohns im deutschen Idealismus. In: Moses Mendelssohn und die Kreise seiner Wirksamkeit. Hg. v. M Albrecht, EJ Engel, N Hinske. Tübingen: Max Niemeyer Verlag; 1994. S. 1-24. (In German).

[34] Danzel ThW. Moses Mendelssohn. In: Danzel ThW. Gesammelte Aufsätze. Hg. v. O Jahn. Leipzig: Duk’schen Buchhandlung; 1855. S. 85-98. (In German).

[35] Erdmann JE. Versuch einer wissenschaftichen Darstellung der Geschichte der neueren Philosophie. Bd. 2. Tl. 2. Leipzig: V.C.W. Vogel; 1842. (In German).

[36] Berghahn C-Fr. „Zur Aktualität Moses Mendelssohns“. In: Moses Mendelssohn. Hg. v. HL Arnold, C-Fr Berghahn. München: Richard Boorberg Verlag; 2011. S. 5-8. (In German).

[37] Albrecht M, Engel EJ, Hinske N. Vorwort. In: Moses Mendelssohn und die Kreise seiner Wirksamkeit. Hg. v. M Albrecht, EJ Engel, N Hinske. Tübingen: Max Niemeyer Verlag; 1994. S. IX-X. (In German).

[38] Levy Z. On Spinoza's and Mendelssohn's Conception of the Relationship between Religion and State. In: Spinoza's Political and Theological Thought. Ed. by C De Deugd. Amsterdam; 1984. P. 107-116.

[39] Sorkin D. Moses Mendelssohn and the Religious Enlightenment. London: Peter Halban; 1996.

[40] Zarek O. Moses Mendelssohn. Ein jüdisches Schicksal in Deutschland. Amsterdam: Querido Verlag; 1937.

[41] Zeller E. Geschichte der deutschen Philosophie seit Leibniz. München: Oldenbourg; 1873. 


\begin{abstract}
About the author:
Kryshtop L.E. - CSc in Philosophy, Associate Professor at Department of History of Philosophy, Faculty of Humanities and Social Science, RUDN University, Moscow, Russia (e-mail: kryshtop-le@rudn.ru).
\end{abstract}

\title{
Концепция религиозного плюрализма М. Мендельсона и ее теоретико-познавательные основания
}

\author{
Л.Э. Крыштоп \\ Российский университет дружбы народов \\ ул. Миклухо-Маклая, д. 6, Москва, Российская Федеращия, 117198
}

Статья посвящена рассмотрению концепции религиозного плюрализма М. Мендельсона и некоторым аспектам его теории познания и языковой теории, являющихся фундаментом теории плюрализма. В статье показывается, что М. Мендельсон высказывал взгляды, далеко опережающие свою эпоху. Его теория познания повторяет некоторые линии размышления Юма, которого он оценивал высоко, что не было характерно для немецкого Просвещения. В силу этого Мендельсона можно считать предшественником Канта в позитивной оценке Юма. Некоторые идеи Мендельсона затем повторяются и получают дальнейшее развитие в феноменологии. В статье аргументировано показывается, что взгляды Мендельсона на взаимодействие религий хотя и имеют ряд черт, роднящих этого мыслителя с другими мыслителями эпохи Просвещения, однако имеют также и принципиальное различие с ними. В итоге, его концепция религиозного плюрализма близка современному пониманию религиозного плюрализма. В статье также предпринимается попытка вскрыть причины, по которым Мендельсон, несмотря на свою колоссальную значимость как для немецкой философии, так и для еврейской культуры, на долгое время был практически забыт.

Ключевые слова: Мендельсон, религия, плюрализм, теория познания, истина, действительность, язык

Информация о финансировании и благодарности. Исследование выполнено при финансовой поддержке РФФИ в рамках научного проекта № 18-011-00080.

\section{История статьи:}

Статья поступила 24.01.2020

Статья принята к публикации 20.04.2020

Для цитирования: Kryshtop L.E. Religious pluralism concept of M. Mendelssohn and its theoretical foundation // Вестник Российского университета дружбы народов. Серия: Философия. 2020. T. 24. No 3. С. 328-341. DOI: 10.22363/2313-2302-2020-24-3-328-341

\section{Сведения об авторе:}

Kpыlumon Людмила Эдуардовна - кандидат философских наук, доцент кафедры истории философии, Российский университет дружбы народов, Москва, Россия (e-mail: kryshtop-le@rudn.ru). 